\title{
Late results of pulmonary root translocation in the correction of transposition of the great arteries
}

\author{
Resultados tardios da translocação da raiz pulmonar na correção da transposição das grandes artérias
}

Luciana da FONSECA ${ }^{1}$, José Francisco BAUMGRATZ ${ }^{1}$, Rodrigo Moreira de CASTRO ${ }^{1}$, Sônia Meiken FRANCHI $^{2}$, José Henrique Andrade VILA², Lílian Maria LOPES ${ }^{3}$, José Pedro da SILVA ${ }^{1}$

RBCCV 44205-653

Abstract

Objective: The purpose of this study was to evaluate the late follow-up of pulmonary root translocation, a technique that aims to avoid complications and the need of reoperations related to the Rastelli procedure, in the repair of ventriculoarterial connection anomalies associated to pulmonary stenosis and ventricular septal defect.

Methods: Five patients, ranging from two months to three years of age, were submitted to anterior pulmonary root translocation, from April 1994 to July 1999. The surgical technique consisted of pulmonary root removal from the left ventricle and its connection to the right ventricle, after patch diversion of the blood flow from the left ventricle to the aorta, through the ventricular septal defect. The construction of the right ventricle outflow tract was completed with autologous pericardium.
Results: There were neither early nor late deaths. There was no need for re-intervention. The late clinical and echocardiographic follow-ups showed some growth of the pulmonary root, with no clinically significant transpulmonary valve gradient (zero to $41 \mathrm{mmHg}$ ) and all patients were asymptomatic.

Conclusion: Pulmonary root translocation showed to be efficient in the repair of ventriculo-arterial connection anomalies, with ventricular septal defect and pulmonary stenosis, and it was employed even in small children, with good early and long-term results, without the need for late reoperations in this small group of patients.

Descriptors: Transposition of Great Arteries. Pulmonary translocation.

Work performed in the São Joaquim da Real Hospital and Benemérita Sociedade Portuguesa de Beneficência Hospital, São Paulo - SP

1 - Cardiovascular surgeons of Beneficência Portuguesa Hospital, São Paulo - SP

2 - Cardiopediatrics of the team of Dr. José Pedro da Silva -Benef. Portuguesa Hospital, São Paulo - SP

3 - Pediatric and fetal echocardiographist of Beneficência Portuguesa Hospital, São Paulo - SP

Correspondence address:

Rua Maestro Cardim 769, sala 202, Paraíso, São Paulo-SP - CEP

01321-001. E-mail: lufonseca@uol.com.br 


\section{Resumo}

Objetivo: Este estudo tem por objetivo avaliar a evolução tardia da translocação da raiz pulmonar, técnica que visa evitar as complicações e a necessidade de reintervenções da operação de Rastelli, na correção de anomalias da conexão ventrículo arterial associados à estenose pulmonar (EP) e comunicação interventricular (CIV).

Método: Cinco pacientes, com idade de dois meses a três anos, foram submetidos à translocação anterior da raiz pulmonar, no período de abril de 1994 a julho de 1999. A técnica consistiu da retirada da raiz pulmonar, com valva, do ventrículo esquerdo (VE) e a sua conexão ao ventrículo direito (VD), após o fluxo do VE ter sido direcionado para a aorta, através da CIV, com placa de teflon. A construção da via de saída do VD foi completada com pericárdio autólogo.

Resultados: Não houve mortalidade precoce ou tardia. Não

\section{INTRODUCTION}

The arterial ventricular connection is called discordant when the right ventricle is connected to the aorta and the left ventricle to the pulmonary artery, commonly called transposition of the great arteries (TGA). The connection is called double outflow tract of the right ventricle (DOTRV) when the great arteries are totally connected or their greatest part is (more than $50 \%$ of the valvar area is superimposed) to the right ventricle [1].

The Rastelli operation [2] is the most commonly used method in the correction of TGA associated with interventricular connections (IVC) and pulmonary stenosis (PS), with good anatomical and physiological results over the short term. However, there are two disadvantages, it is not feasible in some patients owing to a unfavorable intramyocardial anatomy and there is a necessity of an extracardiac tube for reconstruction of the pulmonary outflow tract, with a subsequent necessity of reoperations in the majority of patients [3].

In 1982, LECOMPTE introduced a technique which avoided the use of the valved tube (VER - réparation à l'étage ventriculaire), utilizing the direct re-implantation of the pulmonary branch without a valve in the right ventricle, employing a pericardium monocuspid, as well as making extensive resection of the conal septum [4].

Translocation of the pulmonary root was reported by DA SILVA as a new approach for the correlation of this disease [5], thus avoiding problems with valved tubes or with monocuspids, by maintaining the pulmonary valve functioning.

The aim of this work is to evaluate the clinical and echocardiographic results in the long-term follow-up of this houve necessidade de reintervenção. O seguimento clínico e ecocardiográfico tardio mostra crescimento da raiz pulmonar, sem gradiente transvalvar pulmonar clinicamente significativo (zero a $41 \mathrm{mmHg}$ ) e sem insuficiência valvar pulmonar, com todos os pacientes assintomáticos.

Conclusão: A translocação da raiz pulmonar mostrou-se método eficaz na correção anatômica das anomalias de conexão ventrículo-arteriais associadas a CIV e EP, sendo possível sua utilização mesmo em crianças menores, com bom resultado a curto e longo prazo, demonstrando a não necessidade de reoperações, neste pequeno grupo de pacientes.

Descritores: $\quad$ Transposição das grandes
térias.Translocação Pulmonar.

group of patients, as well as the growth of the pulmonary root, confirming the possibility of exclusion or reduction of the necessity of reoperations.

\section{METHOD}

From April 1994 to July 1999, five patients were submitted to correction surgery of arterial ventricle connection anomalies (TGA and right ventricle septal valve defect RVSVD) associated with IVC and PS, using translocation of the pulmonary root. The patients' ages ranged from 2 months to 3 years, with a mean age of 11 months. Two of the patients were female and 3 male. The data are summarized in Table 1.

Table 1. Patients' preoperative characteristics

\begin{tabular}{ccccc}
\hline PATIENT & AGE & GENDER & DIAGNOSIS & $\begin{array}{c}\text { RV-PB } \\
\text { GRADIENT* }\end{array}$ \\
\hline 1 & 3 YEARS & F & TGA+IVC+PS & 70 \\
2 & 2 MONTHS & M & DOTRV+IVC & 0 \\
3 & 3 MONTHS & M & TGA+IVC+EP & 25 \\
4 & 1 Y 3MONTHS & F & TGA+IVC+EP & 60 \\
5 & 2 MONTHS & M & TGA+IVC+EP & 45 \\
\hline
\end{tabular}

$\mathrm{RV}$ - right ventricle; $\mathrm{M}$ - male; $\mathrm{F}$ - female; $\mathrm{PT}$ - pulmonary branch; TGA - transposition of the great vessels; IVC interventricular connection; PS - pulmonary stenosis, DOTRV double outflow tract of the right ventricle; * Systolic pressure gradient between the right ventricle and the pulmonary artery branch in $\mathrm{mmHg}$. 
Indication criteria included significant TGA, IVC and PS, with size and morphology of the pulmonary valve that was inadequate for the Jatene operation (bicuspid pulmonary valve - patient $\mathrm{N}^{\circ} 3$ ), and a case of DOTRV-type TaussigBing with the right coronary brought forward to where the anterior ascending coronary artery emerged.

The technique employed was the same for all patients, as has been previously described by DA SILVA [5]. After median sternotomy, a part of the pericardium was resected and treated with glutaraldehyde solution. The pulmonary artery and branches were dissected sufficiently to be moved forward to the morphological right ventricle. Cardiopulmonary bypass was installed with aortic and bicaval cannulation and the patient was cooled to $22{ }^{\circ} \mathrm{C}$. Right ventriculotomy was initially performed to assure the position of the IVC in an appropriate site and to check the necessity or not of resection of the conal septum.

The pulmonary root was dissected and removed from the left ventricle with much care so as not to damage the coronary arteries and leaflets of the pulmonary valve. This orifice was then closed using an autologous pericardium patch pre-treated with glutaraldehyde.

By means of right ventriculotomy the IVC was occluded constructing a tunnel from the left ventricle to the aorta, using Dacron sutured with polypropylene 5-0 thread (Figure 1).

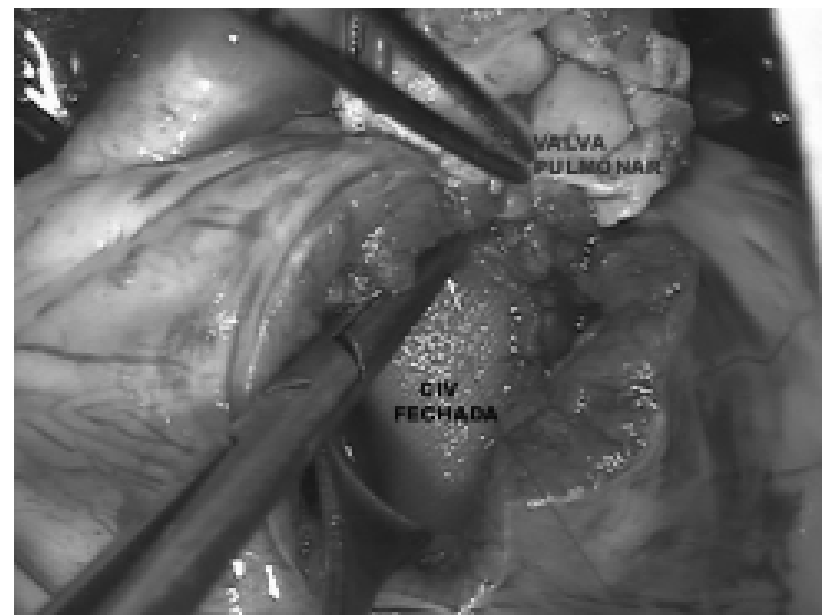

Fig. 1 - Surgical aspect of the pulmonary branch being implanted in the right ventricle outflow tract

Resection of the myocardium of the conal septum was necessary with patient $\mathrm{N}^{\circ} \mathrm{s} 1,2$ and 5 to avoid obstruction of the left ventricle (LV) outflow tract.

The right ventricle outflow tract was reestablished by directly implanting the pulmonary valve in the posterior section of the ventriculotomy and completing the anterior section with autologous pericardium.

In patient $\mathrm{N}^{\mathrm{o}} 1$, who had a small pulmonary valvar ring, a 10 -mm pulmonary valved conduit was added from the most inferior portion of the ventriculotomy to the pulmonary artery. This was made to prevent a high transpulmonary gradient in the initial stage.

Patient $\mathrm{N}^{\circ} 3$ utilized a pedicled pericardium to complete the anterior face of the ventriculotomy, aiming at enabling growth of the pulmonary annulus (Figure 2).

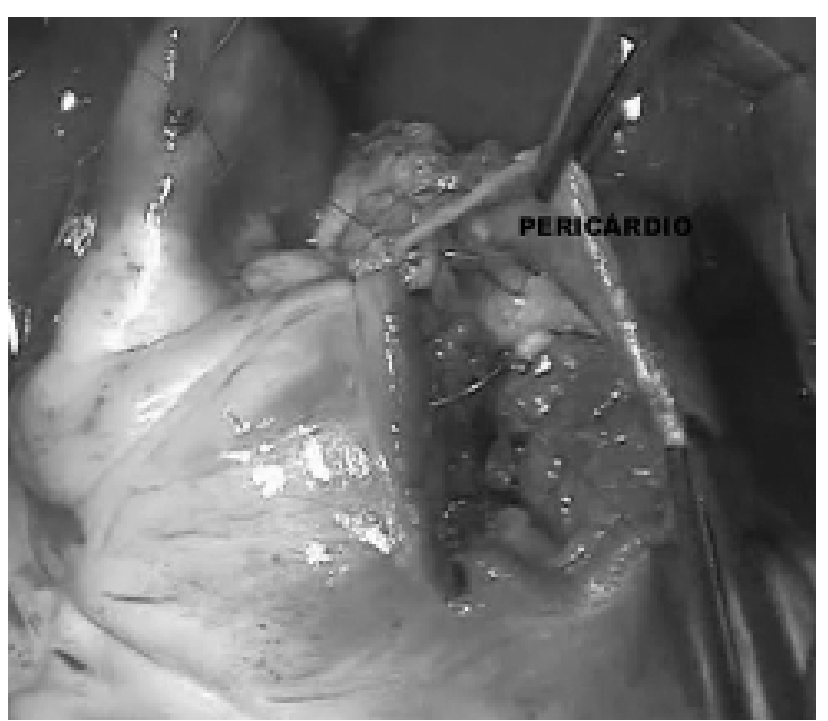

Fig. 2 - Pedicled pericardium used to complete the inferior part of the suture

Clinical assessments and control echocardiographic evaluations were performed before hospital release with all the patients; after 3 months, 6 months and 1 year with the last four patients and after 6 and a half years with the first.

\section{RESULTS}

The follow-up time varied from 1 year to 6 and a half years.

The time of cardiopulmonary bypass ranged from 145 to 180 minutes (mean of 163 minutes), with a mean clamping time of 94 minutes.

All the patients were clinically well at the long-term follow-up, in functional class I (NYHA), without cyanosis or signs of heart failure. In the first 6 post-operative months, 3 patients regularly used furosemid and angiotensin conversion enzyme inhibitor in normal doses for weight and age. Two of these patients were gradually weaned. Sinusal rhythm, without blockers, was observed in all cases. No reintervention has been necessary until now.

Control echocardiographs in the immediate and late postoperative period were obtained from the five patients submitted to this technique. Obstruction of the left ventricle outflow tract was not observed and the pulmonary valve remained competent in all patients (Figures 3 and 4). 


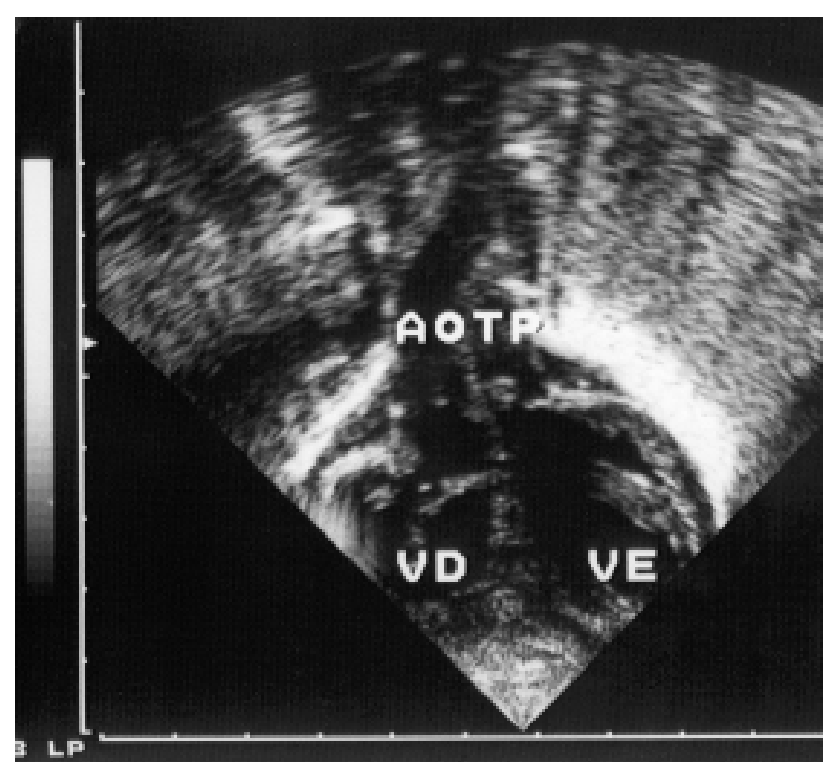

Fig. 3 - Pre-operative echocardiogram demonstrating pulmonary stenosis (A) and interventricular connection (B) with the necessity of resection of the conal septum

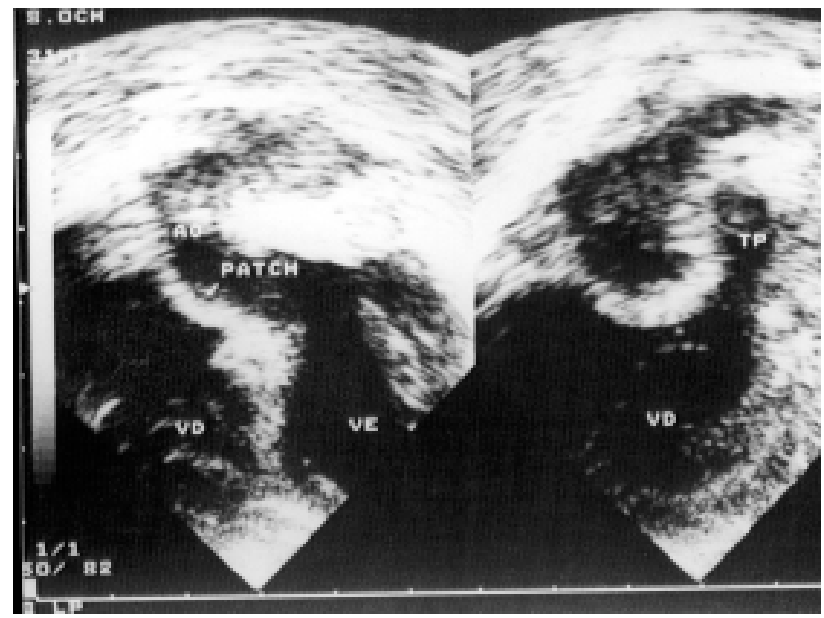

Fig. 4 - Post-operative echocardiogram demonstrating the absence of a left ventricle outflow tract obstruction

The valved conduit grafted in patient $\mathrm{N}^{\circ} 1$ was obstructed in the late echocardiogram.

The RV-PB gradients and size of the pulmonary annuli are summarized in Table 2.

There was no early or late death in this small cohort.

\section{COMMENTS}

The problems related to the Rastelli operation in the long-term follow-up are well known. The lack of growth of the valved conduit and its calcification represent the greatest causes of reoperations in these patients $[3,7]$
Table 2. Echocardiographic control

Pulmonary valvar ring ( $\mathrm{mm})$ / Right ventricle pulmonary branch gradient $(\mathrm{mmHg})$

\begin{tabular}{cccccc}
\hline PATIENT & PRE & RELEASE & 1 year & 3 year & 6 year \\
& OPERATIVE & & & & \\
\hline 1 & $-/ 70$ & $3,2 / 10$ & - & - & $10 / 41$ \\
2 & $-/ 0$ & $10 / 0$ & $12 / 15$ & $16 / 15$ & -- \\
3 & $-/ 25$ & $8 / 25$ & $13 / 40$ & -- & -- \\
4 & $-/ 60$ & $-/ 40$ & $11 / 40$ & -- & -- \\
5 & $-/ 45$ & $8 / 10$ & $14 / 0$ & -- & -- \\
\hline
\end{tabular}

The homologous pulmonary grafts have proved to be more lasting, with a lower rate of calcification and obstruction than aortic grafts, especially in under 4 year-old children $[8,9]$. Although the longevity of the homologous grafts seems to be superior to Dacron tubes, none of these substitutes has the potential of growth and this is one of the reasons that the Rastelli operation is not performed on small children.

Lecompte developed an operation using the pulmonary artery without a valve, which after the transection of the aorta, is brought forward and anastomosed to the right ventricle. The connection is then completed with a monocuspid patch of bovine pericardium for the reconstruction of the anterior part of the right ventricle outflow tract [4]. A similar technique was described by NAGATA in 1997, without transecting of the aorta but also using a monocuspid patch [10].

In the technique employed in our patients, the pulmonary branch remained farther away on dissecting the pulmonary root, associated with extensive dissection and mobilization of the pulmonary branches, enabling anastomosis, without tension of the pulmonary root, to the right ventriculotomy. This also avoided the aortic transection necessary in Lecompte's technique. Preserving the pulmonary valve optimized the physiology in the post-operative period, without early or late pulmonary valvar insufficiency occurring, with growth of the valve over the long-term and without signs of calcification.

The translocation of the pulmonary root has been used as a technique for the correction of double outflow tract of the left ventricle [11]. In the cases described, this technique was applied in a group of different patients, with another type of heart disease and pulmonary stenosis. The translocation of the small pulmonary root enables a certain expansion after dissection from its original position. Additionally, the 
possibility of growth of the pulmonary annulus with the development of the child may evict the necessity of reoperations over the long term. The association of a valved conduit in patient $\mathrm{N}^{\circ} 1$ avoided a high pulmonary transvalvar gradient in the immediate post-operative period. The echocardiogram after 6 and a half years demonstrated the growth of the pulmonary root and the spontaneous closure of the adjunct valved tube, with the child presenting with 9 years old and totally asymptomatic. The pulmonary transvalvar gradient evidenced was $41 \mathrm{mmHg}$. A similar gradient was seen in two other children, after one year of follow up, associated to good right ventricular function and absence of symptoms, and thus without indications for surgery [12].

The pericardium patch used for reconstruction of the right ventricle outflow tract may prejudice the growth of the anterior part of the pulmonary root. In patient $\mathrm{N}^{\circ}$ 3 "in situ" autologous pericardium was used, which may have some potential for growth [13]. The late echocardiogram (3 years) demonstrated a pulmonary valvar ring of $16 \mathrm{~mm}$ with RV-PB gradient of $15 \mathrm{mmHg}$.

Resection of the conal septum in patients $\mathrm{N}^{\circ} \mathrm{s} 1,2$ and 5 evicted obstruction of the left ventricle outflow tract over the long term. Resection of the conal septum is indicated in cases in which the IVC is small or when there is a muscle band between the left ventricle and the aorta, which can cause obstruction in the left ventricle outflow tract after the construction of the left ventricle-aorta tunnel with Dacron [14].

The operative mortality of the Rastelli operation was $10 \%$ in the cohort of MOULTON et al. [3], 19\% for MARCELLETTI et al. [7], 29\% for IMAMURA et al. [15] and $9 \%$ for VOUHÉ et al. [3]. In Lecompte's operation, the early mortality was $18 \%$ for BORROMÉE et al. [6] and $12.5 \%$ for VOUHÉ et al. [3].

The late mortality in the operation of Rastelli is significant: $17 \%$ in the cohort of Moulton and $13 \%$ in the group of Mayo Clinic, with the REV-réparation $\grave{a}$ l'étage ventriculaire procedure this rate is $2 \%$ [3].

In this little cohort there were no cases of early or late mortality and no other procedures have been necessary until now.

The long-term results indicate growth of the pulmonary root, with pulmonary transvalvar gradients without clinical repercussions, with all the patients clinically asymptomatic.

\section{CONCLUSION}

In conclusion, the good results of the late followup demonstrate that the anatomic repair of ventriculo- arterial connection anomalies associated with IVC and PS is possible, with the translocation of the pulmonary root, enabling its utilization even in small children. However the number of patients needs to be increased so that it is possible to establish translocation of the pulmonary root as the method of choice for the treatment of these diseases.

\section{BIBLIOGRAPHIC REFERENCES}

1. Kirklin JW, Barrat-Boyes BG. Cardiac Surgery. 2a ed.New York:Churchill Livingstone Inc;1993.p. 28.

2. Rastelli GC, McGoon DC, Wallace RB. Anatomic correction of transposition of the great arteries with ventricular septal defect and subpulmonary stenosis. J Thoracic Cardiovasc Surg $1969 ;$ 58:545-52.

3. Vouhé PR, Tamisier D, Leca F, Ouaknine R, Vernant F, Neveux JY. Transposition of great arteries, ventricular septal defect and pulmonary outflow tract obstruction. Rastelli or Lecompte procedure? . J Thorac Cardiovasc Surg. 1992; 103 : 428-36.

4. Lecompte Y, Neveux JY, Leca F et al. Reconstruction of the pulmonary outflow tract without prosthetic conduit. J Thorac Cardiovasc Surg . 1982; 84: 727-33

5. Silva JP, Baumgratz JF, Fonseca L. Pulmonary root translocation in transposition of great arteries repair. Ann Thorac Surg . 2000; 69: 643-5.

6. Borromée L, Lecompt Y, Batisse A, et al. Anatomic Repair of anomalies of ventriculo-arterial connection associated with ventricular septal defect.Clinical results in 50 patients with pulmonary outflow tract obstruction. J Thoracic Cardiovasc Surg. 1988; 95:96-102.

7. Marcelletti C, Mair DD, McGoon DC, Wallace RB, Danielson GK. The Rastelli operation for transposition of the great arteries: early and late results. J Thorac Cardiovasc Surg . 1976; 72: 427-34.

8. Yankah AC, Alexi-Meskhishvili V, Weng Y, Berger F, Lange P, Hetzer R. Performance of aortic and pulmonary homograft in the right ventricular outflow tract in children. J Heart Valve Dis. 1995; 4: 392-5.

9. Bando K, Danielson GK, Schaff HV, Mair DD, Julsrud PR, Puga FJ. Outcome of pulmonary and aortic homografts for right ventricular outflow tract reconstruction. J Thorac cardiovasc Surg. 1995; 109: 509-17. 
10. Nagata N. Clinical study of a non conduit repair for complete transposition of great arteries with ventricular septal defect and pulmonary stenosis. Nippon Kiobu Geka Gakkai Zashi. 1997;45: 670-8.

11. McElhinney DB, Reddy M, Hanley FL. Pulmonary root translocation for biventricular repair of double-outlet left ventricle with absent subpulmonic conus. J Thorac Cardiovasc Surg. 1997;114:501-3.

12. Lucena EG,Fagundes CF,Carvalho CR.Anomalias de valva e artérias pulmonares. In: Macruz R, Snitcowsky R. Cardiologia Pediátrica.São Paulo:Sarvier;1983.p.397-407.
13. Hvass U, Khoury W, Subayi JB, Caliani J, Langlois J. The autologous pericardial tube-flap. A new technique for restoring the continuity between the right ventricle and the pulmonary artery. Presse Med. 1997; 16: 2069- 71.

14. Thompson WR, Nichols DG, Ungerleider RM. Double outlet right ventricle and double outlet left ventricle. In: Nichols DG et al. Critical heart disease in infants and children . St. Louis: Mosby- Year Book; 1995. p. 623-48.

15. Imamura ES, Morikawa T, Tatsuno K, Okamoto K, Imai Y. Conduit repairs of transposition complexes.A report of 14 cases. J Thorac Cardiovasc Surg . 1977;73: 570-7. 